\title{
Determinants of MNES Natural Resources Endowments on Performance: An Analytical Model
}

\author{
Luis E. Davila ${ }^{1} \&$ Vijay S. Sampath ${ }^{2}$ \\ ${ }^{1}$ Brooklyn, New York, USA \\ ${ }^{2}$ John Jay College - City University of New York, New York, USA \\ Correspondence: Vijay S. Sampath, John Jay College, 524 West $59^{\text {th }}$ Street, 53341 Haaren Hall, New York, NY \\ 10019, USA.
}

Both authors contributed equally to this paper.

Received: May 4, 2018

doi:10.5539/ibr.v11n7p35

\author{
Accepted: May 25, $2018 \quad$ Online Published: June 5, 2018 \\ URL: https://doi.org/10.5539/ibr.v11n7p35
}

\begin{abstract}
Drawing on the resource-based view and dynamic capabilities' perspectives of the firm, we present a comprehensive analytical model of the key determinants of natural resources endowments (NREs) on the performance of multinational enterprises (MNEs). We also propose four moderators that influence the NRE-performance relationship: private ownership, state ownership, financial resources availability, and research and development efforts. The model makes clear how the various determinants of the NRE-performance relationship impacts international business. The model is designed to motivate empirical research on this topic. Implications to various stakeholders flowing from the proposed model are also discussed.
\end{abstract}

Keywords: natural resources endowments, multinational enterprises, resource-based view of the firm, dynamic capabilities, ownership structure of MNEs, research and development intensity

\section{Introduction}

The world faces political and economic instability that affects not only nations, but individuals and corporations as well. United States (US) and other developed countries' economic prospects are going through an "age of secular stagnation"i (Summers, 2016) because of the tepid recovery from the 2008 financial crisis, inflation, slow economic growth and volatility of commodities prices. A crucial element in the behavior of markets and economies in international business is the open dependency on the availability of natural resources and the geopolitics associated with these resources. Despite challenging economic indicators, multinational enterprises (MNEs) endowed with natural resources are experiencing higher valuation of reserves and stock prices. For instance, the natural resources sector showed strong positive returns for a second consecutive year in 2017, with the S\&P Natural Resources Index gaining 22\% for the year (Blackrock, 2018).

MNEs are also placing emphasis on international expansion. While the natural resources industries are experiencing economic growth, the associated processing industries such as refineries, automotive, microprocessors and diamonds are experiencing diminished growth because of its fragmented nature. Moreover, with recent initiatives on governance and transparency on natural resources management by governments (David - Barrett \& Okamura, 2016) and firms, there are better opportunities for improvement of project returns, in addition to technological innovations that reduce cost in every phase of the projects. Further, the investment in natural resources development keeps growing despite the fall in commodities prices. A World Bank report states that "between 2000 and 2012, investment spending by global oil, gas, and base-metal mining companies rose five-fold, especially in Latin American, the Caribbean, and Sub-Saharan Africa. Including investment in other mined products, global investment in 2011-12 amounted to over \$1 trillion; in Africa, mining investment alone amounted to $\$ 100$ billion in 2011 (or 15 percent of global mining investment) and it was a key driver of growth" (World Bank, 2016: 13). Thus, access, development and trading of natural resources are key for participants in these industries to experience growth.

According to the resource-based view (RBV) of the firm, resources are a major contributor to performance in terms of profits (Wernerfelt, 1984) if they combine capabilities with strategy (Porter, 1980). In this study, we develop a set of propositions for a subset of MNEs having access to valuable natural resources. Firms endowed 
with oil and gas or mine reserves availability have a competitive advantage as they are able to generate "more economic value than the marginal (breakeven) competitor in its product market" (Peteraf \& Barney, 2003, p. 314). Towards this end, we assert that natural resources as part of the bundle of firm resources and capabilities that are valuable, rare, unique and inimitable (Barney, 1991), create conditions for a differentiation strategy aimed at improving firm performance. We develop an analytical model to address the following research questions: Do MNEs that have exclusive access to valuable and rare natural resources on a global basis realize better firm performance than firms in other industries that have other resource availabilities? What are the moderating effects of ownership type, capital markets access and research and development (R\&D) intensity on natural resources endowment (NRE) and performance?

The importance of the subject derives from the fact that firms require complex business strategies to gain long-term exclusive access to rich fields and mines. Those entry- and access-seeking strategies must deal extensively with highly visible environmental and institutional issues (Meyer, Estrin, Bhaumik, \& Peng, 2009), and subsequent restraints, limitations and obstacles. This set of issues become determinants of the development of the investment activity and the demand and display of management capabilities so as to execute the firm's operational activities in a sustainable manner.

As firms develop or structure specific bundles of resources within the same industry (Peteraf \& Barney, 2003), they achieve a sustained competitive advantage. Exclusive access to natural resources for above-average fields and availability of mine reserves create a long-term competitive advantage across firms and industries as much of these resources are immobile (Barney \& Hesterly, 2012). Moreover, exclusive access to these resources, as part of a resource accumulation process (Maritan \& Peteraf, 2011), leads to growth for state-owned and private MNEs (Bass \& Chakrabarty, 2014). To focus on the natural resource exploitation through vertical integration (i.e., diversification), is a profit-seeking strategy that requires more and more access and accumulation of potentially exploitable resources (Amihud \& Lev, 1999).

We also analyze the issue of complementarity of resources and capabilities. Having exclusive access and above-average reserves availability, or just the simple availability of the natural resource, per se, is not sufficient to fulfill the requirement in attaining sustained competitive advantages and superior performance within the industry and across industries (Hoskisson, Eden, Lau, \& Wright, 2000). Within that needed heterogeneity of resources and capabilities (Lippman \& Rumelt, 2003), we argue that the effective use of competitive advantages generated by the exclusive access to an NRE requires a combination of resources and capabilities. Within that combination, dynamic capabilities, as part of a company's internal resource accumulation processes (Maritan \& Peteraf, 2011) are required, including (1) ambidexterity across mature and emerging domains; (2) the ability to manage the upstream business ecosystem; and (3) the ability to manage health, safety, security and environmental considerations in the MNE and throughout the 'business ecosystem' (Shuen, Feiler, \& Teece, 2014).

The contributions of this study are two-fold. Firstly, this study contributes to the field of international business and management by providing an analytical framework to understand the criticality of access to a natural resource endowment for attaining superior performance. It also opens the way for the development of empirical research that can serve as sound evidence for guiding MNEs operating in foreign environments. Secondly, the study will assist in comprehending the implications of having access to natural resources, emphasizing the need for managing the relationship of that access with a series of factors that may affect firm performance through superior returns on the investments made in the development a natural resource base.

In summary, taking advantage of the exclusive access to a valuable, rare, inimitable and non-substitutable natural resource depends on the nature of key moderators of the firm's performance. In this study we analyze: 1) ownership advantages as determined by the access mode to those resources exploitation, 2) the access to capital markets to attain the required financing for the needed investment levels, and 3) the firm's capability to sustain continuous innovation in their specific technological area through research and development efforts.

\section{The Nature of NREs}

We develop our analytical model drawing on the RBV and dynamic capabilities frameworks. According to the RBV framework, for a natural resource endowment to be a major contributor to performance (Barney \& Hesterly, 2012), resources have to be valuable, rare, inimitable and exploitable. The RBV-performance relationship has been studied in different contexts, such as information technology capability (Wu, Yeniyurt, Kim, \& Cavusgil, 2006; Bharadwaj, 2000), manufacturing strategy (Schroeder, Bates, \& Juntilla, 2002), human capital in professional service firms (Hitt, Bierman, Shimizu, \& Kochar, 2017), supply chain linkages (Rungtusanatham, Salvador, Forza, \& Choi (2003), and intellectual capital (Riahi-Belkaoui, 2003). Based on those characteristics, 
natural resources contained in oil and gas fields, as well as mines with high-value minerals exhibit those conditions, if they are simultaneously valuable, rare, imperfectly imitable, and exploitable by the firm's organization. These characteristics would confer both performance and competitive advantages to the MNE (Newbert, 2007). Natural resources either for countries or MNEs are more of a 'blessing' (Haber \& Menaldo, 2011) than a 'curse' (Sachs \& Warner, 1997). Following RBV logic, natural resources access becomes an internal resource for the firm as long as the firm is able to combine it with proper strategies on governance, ownership structure and innovation capabilities. By doing so, the firm would be able to leverage the natural resource endowment in obtaining superior performance.

\subsection{Valuable}

Since the late nineteenth century, the use of oil and gas as commodities expanded through a variety of markets worldwide. The extended utilization of energy resources resulted from the growing substitution of earlier forms of energy use. This created a worldwide demand that historically has equaled or exceeded production targets. Disequilibria in the supply/demand relationship have at times morphed into real economic and political crisis throughout the markets, given the high volatility in prices. This aspect of natural resources makes exclusive access to a natural resource valuable.

The nature of the resource and the exclusive access can generate a high differentiation in exploitation costs because quality and size of the reserves available allows for important competitive advantages. Increases in revenues can come from either exploitation efficiencies or changes in demand and prices or as in the past from price transfer tax gaps that create special returns for oil multinationals (Bernard \& Weiner, 1990). On this topic Phan, Sharma and Narayan (2015) suggest that returns in oil investments are much higher than those in oil consumer sectors.

\subsection{Rarity}

Natural resources with high value are not widely available to all MNEs, they are basically in the hands of a group of specialized multinationals with the capital resources and R\&D capabilities to gain access to regions worldwide. Even though natural resources can be available in abundant quantities, they are usually concentrated in certain geographical areas, thus, availability restraints make them rare by nature. Adding to rareness is the fact that the natural resources industries have been controlled by a very few number of firms, an oligopoly presence in international markets (Barney, 1991), that in some cases have led to 'cartelization' in prices. This state applies to MNEs endowed with NREs such as oil, diamonds, gas, and cooper.

Additionally, the entry costs for firms into highly specialized and valuable natural resources domains demand large amounts of capital and technology that are not available at competitive levels to new firms. The building of processing facilities, such as oil refineries, or diamonds storage and cutting centers, are extremely high for newcomers.

\subsection{Imitability}

Depletion of fields and mines define natural resources as not substitutable, however, when there is a potential substitute that is very different in terms of quantity and quality, this renders substitution imperfect. The development of substitutes for oil, gas, diamonds, steel, etc. are still in early phases of development, with costs of production being higher than those production costs for the natural resource to be substituted. The ability to substitute a certain set of natural resources in terms of quantities, quality and cost, is not possible in many cases. Thus, natural resources are not imitable in ways required for representing a strong competitive advantage for new entrants or a strategic threat to the firms operating in these industries. Similarly, for competitors gaining entry to a natural resource endowment is extremely complex as exploitation of those resources operates under long-term contracts. Access is socially complex as regulations for these sectors demand a strong interaction of a wide set of institutions, groups, entities, and individuals, at both local and international levels. Moreover, political and social connections are usually necessary, as acquisitions of fields and mines depend largely on decisions supported by politically dominant elites or groups. In some cases, monetary incentives are not the only driver for decision-makers because ideological or political motivations may have a key role in the process. As such, financial resources and strong financial position of the firm seeking these rare resources are not sufficient, as strong political backup may be needed.

\subsection{Organization to Exploit Resources}

To exploit a natural resource in terms of effectively having a competitive advantage requires firms to have the organizational structure capable of managing all the related aspects of gaining access. This includes investments in time and resources in managing local elites, sorting political conflicts, applying superior technology, attaining 
adequate financing for own projects and those under joint venture agreements, and gaining political support from home country governments and politicians. These types of capabilities when combined with the value of the natural resource makes a superior combination for adding value and positive performance in comparison to other firms and sectors.

For exploiting and managing natural resources, capabilities and expertise result from the interaction between those environments and internal capabilities within the firm. Firms in the sector develop extensive knowledge bases (Tseng, Tansuhaj, Hallagan, \& McCullough, 2007) in terms of geological, environmental and related resources capabilities. Moreover, research and development capabilities define the nature of the cost structure for those firms operating fields and mines. In sectors such as the oil and gas industry, large amounts of capital required to launch exploration and exploitation activities are only available to firms in the sector with enhanced access capabilities and strong expertise in the variety of institutional environments. Also, the institutional support is not only at the exploitation location, but also at international and home country locations.

Certainly, natural resources per se and exclusive access to them are not, by themselves, sufficient for attaining sustainable competitive advantages, superior performance and above average profits. For an organization attaining superior performance and growth in local and international markets, the level of pressures going through the diverse organization components are equivalent to those felt by individuals coping with the set of goals defined by the firm. Just as individuals go through extenuating levels of organizational stress, firms experience elevated levels of stress in order to achieve the desired results. Herein, we use a theory of motivation at the individual level as an applicable theory at the firm level. Firms struggle for resources, resources conservation and resources expansion. Accordingly, firms, in the same way as individuals, are motivated to protect their current resources and acquire new resources (Halbesleben, Neveu, Paustian-Underdahl, \& Westman, 2014).

\subsection{Dynamic Capabilities within the Firm with Access to NREs}

Natural resource is a unique component of a firm's resources portfolio (Lilach \& Sangyoung, 2011). Teece, Pisano and Shuen (1997) introduced the concept of "dynamic capabilities", as "the sources and methods of wealth creation and capture by private enterprise firms operating in environments of rapid technological change" (p. 509). This enables firms "to enhance enterprise performance and escape the zero-profit tendency associated with operating in markets open to global competition" (Teece, 2007, p. 1319). They are particularly relevant in 'high-velocity' or turbulent markets (Eisenhardt \& Martin, 2000) as they modify other resources and create value.

Capabilities are subsets of the firm's resources, which represent "an organizationally embedded non-transferable firm-specific resource whose purpose is to improve the productivity of the other resources possessed by the firm" (Makadok, 2001, p. 389). They are generally information-based, tangible or intangible processes that enable a firm to deploy its other resources more efficiently and therefore enhance the productivity of those resources. Thus, capabilities are special types of resources whose purpose is to improve the productivity of other resources possessed by the firm (Makadok, 2001).

The advantageous use of the rare and unique resource through dynamic capabilities is the base for structuring successful joint ventures and increasing the financial gains potential for MNEs. The entry mode and exploitation mode organization, together with project financing and research and development capabilities constitute a key set in the profitable exploitation of the natural resources. Dealing with the institutional environment including society and networks is essential for partner selection strategies (Lin, Yang, \& Arya, 2009). Dynamic capability provides useful explanations in that it refers to the ability of a firm to utilize its resources effectively to achieve congruence with the changing business environment.

\section{NREs and Performance}

The performance of the firm in gaining access to a natural resource endowment allows for the accumulation of resources that contributes to its growth at international scales, even at faster rates than competitors in its own sectors or in other sectors. Financial success from attaining an advantageous position in a natural resource market may act as a springboard for multi-nationality. In that respect, Yiu, Lau, and Bruton (2007) suggest that international expansion results from possessing specific resources and advantages associated with exploiting such resources. Chang and Singh (1999) provide evidence on the importance of the firm's resources owned and needed in the effort for expanding operations internationally. Hitt, Tihayni, Miller and Connelly (2006) suggest that possession of an NRE drives a positive association between resource possession and international diversification. The NRE provides returns above average for the firms in that position, given the rareness of the asset, which commands a premium (Barney, 1991), Hence, we raise the following propositions: 
Proposition 1a: The higher the value, rareness, inimitability, and exploitation strategy of a natural resource endowment, the higher the performance of the MNE gaining exclusive access to that endowment.

Proposition 1b: Resource loss or depletion of the resources base is negatively associated with financial performance in non-diversified MNEs.

\subsection{Determinants of NREs on Performance}

In this section we raise propositions about the moderating factors that affect the relationships between NREs and performance: private ownership, state ownership, financial resources availability, and research and development efforts. In figure 1 we present our analytical model of determinants that moderate the NRE-performance relationship.

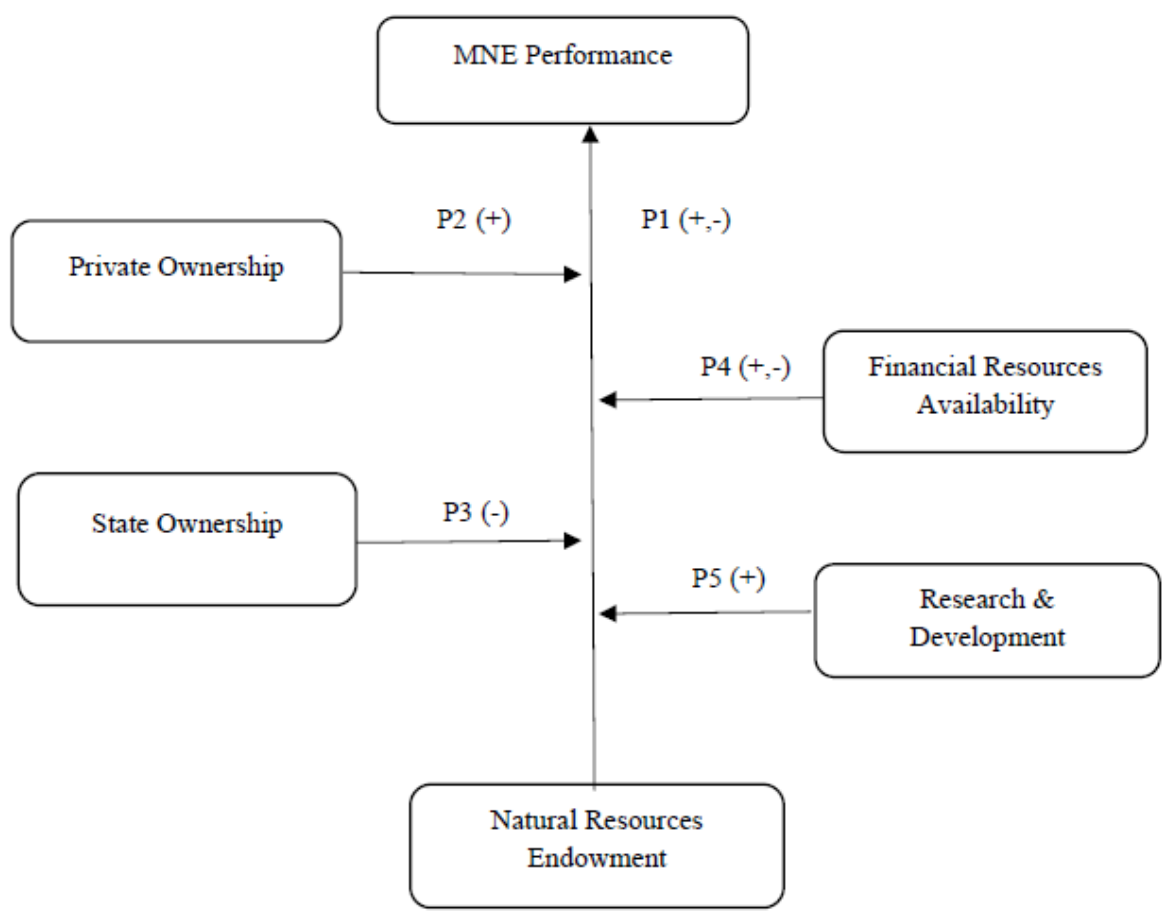

Figure 1. Analytical model of the determinants of MNE national resources endowment and performance

Note. (+) and (-) indicate than an increase in the level of particular determinant would be likely to increase/decrease MNE performance.

\subsection{Ownership Advantages}

MNEs have a set of choices in relation to entry mode. In this respect, Kogut and Singh (1988) classified FDI entry mode into three types: (1) greenfield, (2) acquisition, and (3) joint ventures (JVs). The selection in most cases is in the hands of the corporation, but it must deal with host country regulations and political directives about natural resources exploitation. Consequently, the entry mode selection is intended basically "to overcome different kinds of market inefficiencies related to both characteristics of the resources and to the institutional context" (Meyer et al., 2009, p. 2). For weaker institutional environments, JVs seek to minimize risks related to development of an activity in a sparsely known setting. For that reason, local partners either from the private or public sectors are sought to deal with the institutional issues. However, when foreign direct investments are made in countries where institutional issues are manifold, the issues get muted by the availability of access to valuable natural resources (Aleksynska \& Havrylchyk, 2013). We explore private and state ownership structures to motivate our model.

\subsubsection{Private Ownership}

Ownership structure defines the ownership advantage (Narula \& Nguyen, 2011) derived from natural resources as the value of the asset (e.g., project financing, joint venture bonus payments, early production advanced payments) even if the assets are not being extracted. Variation in asset value in its path from a reserve asset to retail markets is the characterization of the resource heterogeneity (Penrose, 1959).

Access for natural resource exploitation is subject to complex institutional idiosyncrasies (Yiu et al., 2007), and 
dynamics (Lockett, Thompson, \& Morgenstern, 2009). The ownership rights and structures, resulting from state and private types of ownership (Hautz, Mayer, \& Stadler, 2013; Porta, Lopez-De-Silanes, \& Shleifer, 1999), are moderators of the relationship between natural resources access and MNE performance. For a joint venture to be successful in the exploitation of a natural resource with exclusive access, the firm needs to be in control of operations and management in order to reduce costs and maximize profits. Entering into a JV with a large ownership position minimizes the effects of political and social issues of the governmental partners. Wang \& Shailer (2018, p. 1) find that, "on average, the underlying ownership performance relation is negative for government ownership and positive for private ownership, and the difference between these relations is significant." Along the same lines, Arocena and Oliveros (2012) suggest that firms after leaving government ownership through privatization improved their financial performance. Similarly, Frydman, Gray, Hessel and Rapaczynski (1999) found that in cases where privatization is effective the increase in revenues was 'pronounced'. Accordingly,

Proposition 2: The relationship between a firm's natural resources endowment and performance is positively moderated when the MNE is the largest block holder in a joint venture with State-Owned Enterprises.

\subsubsection{State Ownership}

The relationship between state ownership and performance is relevant because the level of state ownership, plays a role in the internationalization strategy of firms (Child \& Rodrigues, 2005). While state ownership in a JV to exploit a natural resource might be necessary in order to pair country needs with the firm's strategies (Cui \& Jiang, 2012; Amihud \& Lev, 1999), it is certainly a factor for managing better host country uncertainties and risks (Amighini, Rabellotti, \& Sanfilippo, 2012). In a study related to performance of Chinese MNEs that invest outside China, Cui and Jiang (2012) found that state ownership creates institutional pressures on firms to adopt a specific ownership structure, thus, performance does not necessarily benefit the most efficient business organization. Political objectives dominate the firm's actions, and while managers interact with owners seeking to minimize their impact, it results in increased costs (Shleifer \& Vishny, 1994). On the other hand, there are severe issues in information transparency on operational results and earnings management, with low stock price informativeness, which depends on political institutions being "more pronounced in countries with lower political rights" (Ben-Nasr \& Cosset, 2014, p. 179). Hence,

Proposition 3: The relationship between a firm's natural resources endowment and performance is negatively moderated when there is a majority state ownership position in a joint venture with an MNE.

\subsection{Financial Resources Availability}

Financial capital acquisition capabilities are an enhancement of natural resources access management capabilities to develop a capital market financing base and improving productivity of the resources (Makadok, 2001). Capital market access derives from lenders and investors risk perceptions because high levels of technological, political and commercial risks associated with natural resources management represent a barrier to multi-nationality. Thus, firms with overall lower risk perceptions by investors display higher degrees of multi-nationality. Credit ratings define the cost of debt which is found to be inversely related to multi-nationality (Reeb, Mansi, \& Allee, 2001). Thus,

Proposition 4a: High debt ratios positively moderate the relationship between a firm's natural resources endowment and performance, when the MNE has a controlling position in a joint venture with a State-Owned Enterprise (<. 50).

Proposition 4b: High debt ratios negatively moderate the relationship between a firm's natural resources endowment and performance, when there is a state ownership controlling position in a joint venture with the MNE (<. 50).

\subsection{Research and Development Efforts}

R\&D constitutes a key factor within the resources bundle (Wernerfelt, 1984) of the firm. A firm with a valuable, rare, not imitable, and non-substitutable natural resource (Barney, 1991) runs the risk of being underexploited or lost to competition if the firm does not have the capability or access to technology for sustainable and efficient exploitation of the resource (Rumelt, 1982). R\&D eases development of absorptive capacities, either from complementary and competing technologies or from internal routines and processes (Nelson \& Winter, 1982). Patents for new technologies are relevant in natural resources exploitation industries for assessing, measuring, drilling, mining, storing, transporting, refining, etc. Patents not only allow for enhanced access to the resources exploitation but also for attaining cost efficiencies in trade activities (Hsu \& 
Ziedonis, 2013).

Globalization, climate change, transparency issues, and global sustainability are major drivers of innovative technology and disruptive innovation. Particularly demanding for firms in the natural resources sectors is the development of added capabilities to deal with social, political and economic issues, where appropriate management of those issues makes the differences in returns. Thus, R\&D involves the optimal exploitation of old fields and mines, the conservation of business ecosystems, and the improvement of protection systems that reduces costs and risks from health, safety, security and environmental concerns (Shuen et al., 2014). Thus, we raise the following proposition:

Proposition 5: R\&D intensity positively moderates the relationship between natural resources endowment and performance for an MNE.

\section{Implications and Conclusions}

The aim of this paper has been to develop an analytical model to analyze the influence of valuable and rare natural resources on an MNE's performance. To do so, we have drawn on the RBV and the dynamic capabilities frameworks. According to RBV logic, the valuable, rare, imperfectly imitable, and exploitable characteristics of natural resources gives MNEs exclusive access to these assets, thereby conferring to them the ability to experience superior performance. In order to gain long-term exclusive access to natural resources, MNEs must develop dynamic capabilities at the firm level to successfully exploit the exclusivity advantages. We have raised propositions on the determinants that impact the natural resources-MNE performance relationship: private ownership, state ownership, financial resources availability and R\&D intensity. Thus, this paper has aimed to contribute to the body of knowledge in international business by demonstrating the importance of natural resources endowments on MNE performance.

We hope that our study starts a new area of inquiry with productive avenues for research. Designing research to test the propositions will require partnering with MNEs with natural resource endowments to collect data for analysis. The research could initially take a case-oriented approach with empirical validation sought by using methods such as Qualitative Comparative Analysis (QCA). One of the primary advantages of using QCA is the ability to analyze data for small and intermediate size samples (Rihoux, 2006). Such research would develop a more detailed understanding of the proposed framework, which would spur hypothesis-testing work in the future.

The analytical model for NREs and performance proposed by us has a number of implications for various stakeholders. For MNEs in the natural resources sectors, the approach we develop can be helpful in training and development of country managers and personnel dedicated to lobbying and negotiating of access to fields and mines with valuable natural resources, demanding necessary investments and infrastructure development. For managers dealing with international diversification, they can adopt the dynamic capabilities framework to internally develop capabilities to successfully exploit natural resources endowments. In regard to management of R\&D for natural resources exploitation and processing, our approach provides guidance about the use of patents and new technologies that would allow for enhanced access for exploitation of resources and attainment of cost efficiencies. For governments in nations with natural resources endowments, local politicians and politicians in host countries can learn how to deal with MNEs for further development of any natural resources at hand. Countries and local government officials need to understand that development of those resources is key for improving not only the fiscal balances of a country or a local government, but for improving the general well-being of the population at large. The exploitation of a pool of natural resources can be a real blessing for both the owner of the resource and the firm to exploit them, as long as a long-term vision is present. MNEs have to plan extensively for the magnitude of the financial resources to be applied, the feasibility of attaining those financing levels and the stability of the socio-economic environment. In addition, this study starts a conversation, combining the fields of international business and political economy and allowing for the identification of different sets of relationships. Future research would include examining (a) the role of MNEs in host country growth rates vis-à-vis entry mode strategy and levels of state ownership in joint ventures; (b) political instability and property rights enforcement for MNEs having access to natural resources endowments; and, (c) corporate governance in joint ventures exploiting an NRE and its effects on performance.

While exploitation of NREs provides MNEs with performance benefits, we caution stakeholders about the presence of corruption in the natural resources sector (Arezki \& Bruckner, 2011) that gives rise to societal governance challenges (Frynas, 2010). MNEs have to protect their legitimacies when transacting in corruption-prone host countries (Sampath \& Rahman, 2018). These authors suggest that MNEs institute and enforce ethical codes of conduct in their host country operations. 
In summary, we hope this article contributes toward a better understanding of the factors that determine the impact of natural resources endowments on MNE performance. The analytical model proposed here would be able to facilitate a robust discussion and study of the determinants of MNE performance in regard to NREs, thus far inadequately examined as an area in international business research.

\section{References}

Aleksynska, M., \& Havrylchyk, O. (2013). FDI from the south: The role of institutional distance and natural resources. European Journal of Political Economy, 29, 38-53. https://doi.org/10.1016/j.ejpoleco.2012.09.001

Amighini, A., Rabellotti, R., \& Sanfilippo, M. (2012). Outward FDI from developing country MNEs as a channel for technological catch-up. In P. Cooke, \& J. L. Curbelo, M. D. Parrilli (Eds), Innovation, global change and territorial resilience (pp. 215-229). Northampton: Edward Elgar. https://doi.org/10.4337/9780857935755.00018

Amihud, Y., \& Lev, B. (1999). Does corporate ownership structure affect its strategy towards diversification? Strategic Management Journal, 20(11), 1063-1069. https://doi.org/10.1002/(SICI)1097-0266(199911)20:11<1063::AID-SMJ69>3.0.CO;2-S

Arezki, R., \& Bruckner, M. (2011). Oil rents, corruption, and state stability: Evidence from panel data regressions. European Economic Review, 55(7), 965-963. https://doi.org/10.1016/j.euroecorev.2011.03.004

Arocena, P., \& Oliveros, D. (2012). The efficiency of state-owned and privatized firms: Does ownership make a difference? International Journal of Production Economics, 140(1), 457-465. https://doi.org/10.1016/j.ijpe.2012.06.029

Barney, J. (1991). Firm resources and sustained competitive advantage. Journal of Management, 17(1), 99-120. https://doi.org/10.1177/014920639101700108

Barney, J., \& Hesterly, W. (2012). Strategic management and competitive advantage: Concepts and cases. New Jersey: Pearson.

Bass, A. E., \& Chakrabarty, S. (2014). Resource security: Competition for global resources, strategic intent, and governments as owners. Journal of International Business Studies, 45(8), 961-979. https://doi.org/10.1057/jibs.2014.28

Ben-Nasr, H., \& Cosset, J. C. (2014). State ownership, political institutions, and stock price informativeness: Evidence from privatization. Journal of Corporate Finance, 29, 179-199. https://doi.org/10.1016/j.jcorpfin.2014.10.004

Bernard, J. T., \& Weiner, R. (1990). Multinational corporations, transfer prices, and taxes: Evidence from the US petroleum industry. Taxation in the global economy (pp. 123-160). Chicago: University of Chicago Press.

Bharadwaj, A. S. (2000). A resource-based perspective on information technology capability and firm performance: An empirical investigation. MIS Quarterly, 24(1), 169-196. https://doi.org/10.2307/3250983

Blackrock. (2018). Natural resources 2018: The resurgence. Retrieved from https://www.blackrock.com/investing/literature/investor-education/2018-outlook-natural-resources-cef.pdf

Chang, S. J., \& Singh, H. (1999). The impact of modes of entry and resource fit on modes of exit by multibusiness firms. Strategic Management Journal, 20(11), 1019-1035. https://doi.org/10.1002/(SICI)1097-0266(199911)20:11<1019::AID-SMJ66>3.0.CO;2-9

Child, J., \& Rodrigues, S. B. (2005). The Internationalization of Chinese Firms: A Case for Theoretical Extension? Management and Organization Review, 1(3), 381-410. https://doi.org/10.1111/j.1740-8784.2005.0020a.x

Cui, L., \& Jiang, F. (2012). State ownership effect on firms' FDI ownership decisions under institutional pressure: A study of Chinese outward-investing firms. Journal of International Business Studies, 43(3), 264-284. https://doi.org/10.1057/jibs.2012.1

David-Barrett, E., \& Okamura, K. (2016). Norm diffusion and reputation: The rise of the extractive industries transparency initiative. Governance, 29(2), 227-246. https://doi.org/10.1111/gove.12163

Eisenhardt, K. M., \& Martin, A. (2000). Dynamic capabilities: What are they? Strategic Management Journal, 21, 1105-1121. https://doi.org/10.1002/1097-0266(200010/11)21:10/11<1105::AID-SMJ133>3.0.CO;2-E

Frydman, R., Gray, C., Hessel, M., \& Rapaczynski, A. (1999). When does privatization work? The impact of 
private ownership on corporate performance in the transition economies. The Quarterly Journal of Economics, 114(4), 1153-1191. https://doi.org/10.1162/003355399556241

Frynas, J. G. (2010). Corporate social responsibility and societal governance: Lessons from transparency in the oil and gas sector. Journal of Business Ethics, 93(2), 163-179. https://doi.org/10.1007/s10551-010-0559-1

Haber, S., \& Menaldo, V. (2011). Do natural resources fuel authoritarianism? A reappraisal of the resource curse. American Political Science Review, 105(1), 1-26. https://doi.org/10.1017/S0003055410000584

Halbesleben, J. R., Neveu, J. P., Paustian-Underdahl, S. C., \& Westman, M. (2014). Getting to the "COR" understanding the role of resources in conservation of resources theory. Journal of Management, 40(5), 1334-1364. https://doi.org/10.1177/0149206314527130

Hautz, J., Mayer, C. M. J., \& Stadler, C. (2013). Ownership identity and concentration: A study of their joint impact on corporate diversification. British Journal of Management, 24(1), 102-126. https://doi.org/10.1111/j.1467-8551.2011.00792.x

Hitt, M. A., Bierman, L., Shimizu, K., \& Kochhar, R. (2017). Direct and moderating effects of human capital on strategy and performance in professional services firms: A resource-based perspectives. Academy of Management Journal, 44(1). https://doi.org/10.5465/3069334

Hitt, M. A., Tihanyi, L., Miller, T., \& Connelly, B. (2006). International diversification: Antecedents, outcomes, and moderators. Journal of Management, 32(6), 831-867. https://doi.org/10.1177/0149206306293575

Hoskisson, R. E., Eden, L., Lau, C. M., \& Wright, M. (2000). Strategy in Emerging Economies. Academy of Management Journal, 43(3), 249-267.

Hsu, D. H., \& Ziedonis, R. H. (2013). Resources as dual sources of advantage: Implications for valuing entrepreneurial - firm patents. Strategic Management Journal, 34(7), 761-781. https://doi.org/10.1002/smj.2037

Kogut, B., \& Singh, H. (1988). The effect of national culture on the choice of entry mode. Journal of International Business Studies, 19(3), 411-432. https://doi.org/10.1057/palgrave.jibs.8490394

Lilach, N., \& Sangyoung, S. (2011). The MNE as a portfolio: Interdependencies in MNE growth trajectory. Journal of International Business Studies, 42(3), 381-405. https://doi.org/10.1057/jibs.2010.60

Lin, Z., Yang, H., \& Arya, B. (2009). Alliance partners and firm performance: resource complementarity and status association. Strategic Management Journal, 30(9), 921-940. https://doi.org/10.1002/smj.773

Lippman, S. A., \& Rumelt, R. P. (2003). A bargaining perspective on resource advantage. Strategic Management Journal, 24(11), 1069-1086. https://doi.org/10.1002/smj.345

Lockett, A., Thompson, S., \& Morgenstern, U. (2009). The development of the resource-based view of the firm: A critical appraisal. International Journal of Management Reviews, 11(1), 9-28. https://doi.org/10.1111/j.1468-2370.2008.00252.x

Makadok, R. (2001). Towards a synthesis of the resource-based and dynamic-capability views of rent creation. Strategic Management Journal, 22(5), 387-401. https://doi.org/10.1002/smj.158

Maritan, C. A., \& Peteraf, M. A. (2011). Building a bridge between resource acquisition and resource accumulation. Journal of Management, 37(5), 1374-1389. https://doi.org/10.1177/0149206310387675

Meyer, K. E., Estrin, S., Bhaumik, S. K., \& Peng, M. W. (2009). Institutions, resources, and entry strategies in emerging economies. Strategic Management Journal, 30(1), 61-80. https://doi.org/10.1002/smj.720

Narula, R., \& Nguyen, Q. T. K. (2011). Emerging country MNEs and the role of home countries: Separating fact from international expectations. United Nations University Working Paper Series.

Nelson, R. R., \& Winter, S. G. (1982). The Schumpeterian tradeoff revisited. American Economic Review, 72(1), $114-132$.

Newbert, S. L. (2007). Empirical research on the resource-based view of the firm: An assessment and suggestions for future research. Strategic Management Journal, 28, 121-146. https://doi.org/10.1002/smj.573

Penrose, E. T. (1959). The theory of the growth of the firm. New York: Sharpe.

Peteraf, M. A., \& Barney, J. B. (2003). Unraveling the resource-based tangle. Managerial and Decision Economics, 24(4), 309-323. https://doi.org/10.1002/mde.1126 
Phan, D. H. B., Sharma, S. S., \& Narayan, P. K. (2015). Oil price and stock returns of consumers and producers of crude oil. Journal of International Financial Markets, Institutions and Money, 34, 245-262. https://doi.org/10.1016/j.intfin.2014.11.010

Porta, R. L., Lopez-De-Silanes, F., \& Shleifer, A. (1999). Corporate ownership around the world. Journal of Finance, 54(2), 471-517. https://doi.org/10.1111/0022-1082.00115

Porter, M. E. (1980). Industry structure and competitive strategy: Keys to profitability. Financial Analysts Journal, 36(4). https://doi.org/10.2469/faj.v36.n4.30

Reeb, D. M., Mansi, S. A., \& Allee, J. M. (2001). Firm internationalization and the cost of debt financing: Evidence from non-provisional publicly traded debt. Journal of Financial and Quantitative Analysis, 36(3), 395-414. https://doi.org/10.2307/2676289

Riahi - Belkaoui, A. (2003). Intellectual capital and firm performance of US multinational firms: A study of the resource - based and stakeholder views. Journal of Intellectual Capital, 4(2), 215-226. https://doi.org/10.1108/14691930310472839

Rihoux, B. (2006). Qualitative Comparative Analysis (QCA) and related systematic comparative Methods. International Sociology, 21(5), 679-706. https://doi.org/10.1177/0268580906067836

Rumelt, R. P. (1982). Diversification strategy and profitability. Strategic Management Journal, 3(4), 359-369. https://doi.org/10.1002/smj.4250030407

Rungtusanatham, M., Salvador, F., Forza, C., \& Choi, T. Y. (2003). Supply - chain linkages and operational performance: A resource - based - view perspective. International Journal of Operations \& Production Management, 23(9), 1084-1099. https://doi.org/10.1108/01443570310491783

Sachs, J. D., \& Warner, A. M. (1997). Natural resource abundance and economic growth. In G. Meier and J. Rauch (eds.), Leading Issues in Economics, Oxford University Press: Oxford.

Sampath, V., \& Rahman, N. (2018). MNEs and bribery: The dynamics of corruption culture distance and organizational distance to core values. Journal of Business Ethics. https://doi.org/10.1007/s10551-018-3827-0

Schroeder, R. G., Bates, K. A., \& Juntilla, M. A. (2002). A resourced-based view of manufacturing strategy and the relationship to manufacturing performance. Strategic Management Journal, 23(2), 105-117. https://doi.org/10.1002/smj.213

Shleifer, A., \& Vishny, R. W. (1994). Politicians and firms. Quarterly Journal of Economics, 109(4), 995-1025. https://doi.org/10.2307/2118354

Shuen, A, Feiler, P. F., \& Teece, D. J. (2014). Dynamic capabilities in the upstream oil and gas sector: Managing next generation competition. Energy Strategy Reviews, 3, 5-13. https://doi.org/10.1016/j.esr.2014.05.002

Summers, L. H. (2016). The age of secular stagnation. Foreign Affairs. Retrieved from https://www.foreignaffairs.com/articles/united-states/2016-02-15/age-secular-stagnation

Teece, D. J. (2007). Explicating dynamic capabilities: The nature and microfoundations of (sustainable) enterprise performance. Strategic Management Journal, 28(13), 1319-1350. https://doi.org/10.1002/smj.640

Teece, D. J., Pisano, G., \& Shuen, A. (1997). Dynamic capabilities and strategic management. Strategic Management Journal, 18(7), 509-533. https://doi.org/10.1002/(SICI)1097-0266(199708)18:7<509::AID-SMJ882>3.0.CO;2-Z

Tseng, C. H., Tansuhaj, P., Hallagan, W., \& McCullough, J. (2007). Effects of firm resources on growth in multinationality. Journal of International Business Studies, 38(6), 961-974. https://doi.org/10.1057/palgrave.jibs.8400305

Wang, K. T., \& Shailer, G. (2018). Does ownership identity matter? A meta - analysis of research on firm financial performance in relation to government versus private ownership. Abacus, 54(1), 1-35. https://doi.org/10.1111/abac.12103

Wernerfelt, B. (1984). A resource-based view of the firm. Strategic Management Journal, 5(2), 171-180. https://doi.org/10.1002/smj.4250050207

World Bank. (2016). Special focus: Resource development in an era of cheap commodities. Retrieved from http://pubdocs.worldbank.org/en/520771461694380642/CMO-April-2016-Special-Focus.pdf

Wu, F., Yeniyurt, S., Kim, D., \& Cavusgil, S. T. (2006). The implications of information technology on supply 
chain capabilities and firm performance: A resource-based view. Industrial Marketing Management, 35(4), 493-504. https://doi.org/10.1016/j.indmarman.2005.05.003

Yiu, D. W., Lau, C., \& Bruton, G. D. (2007). International venturing by emerging economy firms: The effects of firm capabilities, home country networks, and corporate entrepreneurship. Journal of International Business Studies, 38(4), 519-540. https://doi.org/10.1057/palgrave.jibs.8400278

${ }^{\mathrm{i}}$ Secular stagnation refers to conditions when there is little to no economic growth in market-based economies. This is due to imbalances arising from 'propensities' to save and invest (Summers, 2016).

\section{Copyrights}

Copyright for this article is retained by the author(s), with first publication rights granted to the journal.

This is an open-access article distributed under the terms and conditions of the Creative Commons Attribution license (http://creativecommons.org/licenses/by/4.0/). 